\title{
CONFIRMING THE PRESENCE OF HTLV-1 INFECTION AND THE ABSENCE OF HTLV-2 IN BLOOD DONORS FROM AREQUIPA, PERU
}

\author{
Nadia Carmela Santos QUISPE(1), Edwin Bengoa FERIA(2), Elizabeth de los SANTOS-FORTUNA(3) \& Adele CATERINO-DE-ARAUJO(3)
}

\begin{abstract}
SUMMARY
Epidemiological studies conducted in Peru disclosed HTLV-1 to be prevalent in different ethnic groups, and found HTLV-2 in some Amazonian Indians and in men who have sex with men. No data concerning HTLV-1/2 infection in blood donors from Arequipa, a highlands region in southern Peru, is available. We searched for the presence of HTLV-1 and HTLV-2 antibodies in 2,732 serum samples obtained from blood donors from this geographic area. HTLV-1/2-specific antibodies were detected using an enzyme-linked immunosorbent assay (ELISA) and were confirmed by Western blot (WB). Reactive sera had their blood bags discarded from donation, and the demographic characteristics of the donors were analyzed. Thirty-five sera (1.2\%) were HTLV seroreactive by ELISA, and 25 were confirmed HTLV-1-positive by WB. One serum disclosed HTLV-positivity, and the remaining nine serum samples showed indeterminate results by WB; three of which had an HTLV-1 indeterminate Gag profile. The median age of HTLV-positive individuals was 34.6 years; 27 were male and eight were female. All individuals were from southern Peru: 27 from Arequipa, five from Puno, and three from Cuzco. HTLV co-positivity with hepatitis B (five sera) and syphilis (one serum) were detected. Previous transfusion and tattooing were observed in two and one individuals, respectively. No serum was positive for HTLV/HIV co-infection. This study confirmed, for the first time, HTLV-1 infection and the absence of HTLV-2 infection in blood donors from Arequipa, Peru and suggests vertical transmission as the major route of HTLV-1 transmission and acquisition in this geographic region.
\end{abstract}

KEYWORDS: Human T cell lymphotropic virus 1 (HTLV-1); HTLV-2; Serology; Blood donors; Peru.

\section{INTRODUCTION}

In June 1998, the Ministry of Health of Peru required mandatory serology screening for HTLV-1/2 in blood centers and recommended to discard blood bags positive for such diseases/pathogens ${ }^{20}$. Antibodies to HTLV-1/2 have been screened by agglutination tests and enzyme-linked immunosorbent assays (ELISA). Confirmatory and discriminatory tests were immunofluorescence assay (IFA) and Western Blot (WB), but these were not compulsory for blood banks in Peru.

Several epidemiological studies on HTLV-1/2 infection have been conducted in Peru, but the majority of them are related to high-risk or at-risk populations, such as HTLV-1-associated myelopathy/tropical spastic paraparesis (HAM/TSP) patients, men who have sex with men (MSM), patients with sexually transmitted diseases (STDs), and female sex workers $(\mathrm{FSW})^{8,9,11,26,28,29}$.

HTLV-1 is endemic in several Peruvian populations. Among healthy women, a study conducted in three Peruvian regions disclosed HTLV-1 rates of $1.3 \%$ in Huanta (an Andean city inhabited by indigenous Quechuas), $3.8 \%$ in El Carmen (an African-American coastal town), and 3.8\% in Lima (a city of Mestizo population in Peru) ${ }^{24}$. In pregnant women throughout Peru, $1.7 \%$ were infected with HTLV-1. Among them, seroprevalence increased with age but did not vary by region of birth ${ }^{1}$. HTLV-1 infection is also frequent in the offspring of Peruvian HTLV-1-infected women, showing frequencies of $6 \%$ among children from asymptomatic mothers, $19 \%$ in children whose mother has HAM/TSP, and $31 \%$ among offspring of mothers with strongyloidiasis ${ }^{10}$. An epidemiological study conducted among at-risk individuals from Cuzco and Quillabamba, both in southern Peru, suggested that HTLV-1 is endemic in this region ${ }^{29}$.

Curiously, HTLV-1 is also endemic among Amerindians in Peru, a population thought to be infected with HTLV-2 in several countries of Latin America ${ }^{7,13,19,22}$. Nevertheless, HTLV-2 was only detected in two Peruvian Amazonian Indians and in several MSM from Peru ${ }^{19,28}$.

Little is known about HTLV-1/2 infection in blood-transfused patients and in blood donors from Peru ${ }^{12,17}$. Thus, the present study aimed to add information concerning blood donors from Arequipa, a city located in a highlands region of southern Peru whose population has Mestizo (Spanish-Indian) origin. We searched for the presence of HTLV-1- and HTLV-2-specific antibodies and tried to identify modes

Support: CNPq, Instituto Adolfo Lutz.

(1) Hospital Goyeneche, Arequipa, Peru.

(2) Hospital Honorio Delgado Espinoza, Arequipa, Peru.

(3) Instituto Adolfo Lutz, São Paulo, SP, Brasil.

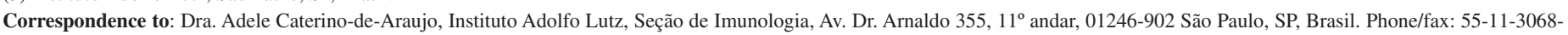
2898. E-mail: caterino@ial.sp.gov.br; caterino@usp.br 
QUISPE, N.C.S.; FERIA, E.B.; SANTOS-FORTUNA, E. \& CATERINO-DE-ARAUJO, A. - Confirming the presence of HTLV-1 infection and the absence of HTLV-2 in blood donors from Arequipa, Peru. Rev. Inst. Med. trop. S. Paulo, 51(1): 25-29, 2009.

of virus transmission/acquisition by analyzing demographic risk factors obtained from a blood donation questionnaire.

\section{MATERIALS AND METHODS}

Study population: During 2005, all blood donors from Hospital Goyeneche and Hospital Honorio Delgado Espinoza, Arequipa, Peru ( $\mathrm{n}=$ 2,732) had their blood screened for the presence of six blood transmitted diseases (HIV, HTLV-1/2, HBV, HCV, Chagas disease, and syphilis). Serum samples were analyzed for the presence of specific antibodies to HTLV-1/2 using an ELISA kit that employs HTLV-1/2 viral lysates plus recombinant proteins from HTLV-1/2 as antigens (Vironostika HTLV-I/II, Organon Teknika, Durhan, DC). The reactions were conducted according to manufacturer instructions. Sera that produced OD/cutoff $\geq 1.0$ were considered reactive for HTLV-1/2 antibodies and excluded from blood donation.

Additionally, HTLV-1/2-positive sera were sent to Instituto Adolfo Lutz (IAL), a public heath laboratory of São Paulo, Brazil, for confirming and discriminating HTLV-1- from HTLV-2-seropositive samples. The algorithm tests used by IAL for HTLV-1/2 diagnosis employ two ELISAs of different formats and compounds as screening, and WB as a confirmatory assay ${ }^{16}$. The kits used for screening were Vironostika HTLV-I/II (BioMerieux, France) and BioELISA HTLV-I+II (r) (BioKit S.A., Spain), and for confirmatory test, WB 2.4 (Genelabs Diagnostics, Singapore). The reactions were conducted according to manufacturers' instructions. WB results were stringently evaluated, with HTLV-1 positivity defined as reactivity to Gag (p19 with or without p24) and two Env (GD21 and rgp46-I) bands, and HTLV-2 positivity defined as reactivity to Gag (p24 with or without p19) and two Env (GD21 and rgp46-II) bands. Reactivity to Gag (p19 and p24) and Env (GD21) denoted HTLV positivity. Reactivity to Gag (p19 and p24) and Env (GD21, rgp46-I and rgp46-II) bands defined HTLV-1 and HTLV-2 seropositivity. Any other pattern of bands was considered indeterminate.

The HTLV-1/2-positive results were analyzed in relation to demographic characteristics of blood donors obtained from a questionnaire which included age, gender, local of origin and residence, and factors for infection (e.g., previous blood transfusion, history of acupuncture, previous surgery, hepatitis, tattooing, intravenous drug use (IDU), and genital ulcer). In addition, sexual behaviors-history of STDs, sexual contact with sex workers, number of partners in the last three years, homosexual contact, use of condom during sexual intercourse, and others - were evaluated.

The study was approved by the Ethics Committees of Institutions, and by the Dirección Regional de Salud, Arequipa, Peru.

\section{RESULTS}

Out of 2,732 blood samples, 35 (1.2\%) resulted HTLV-1/2-positive in screening tests conducted in Peru and were sent to IAL for confirmatory analyses. All sera confirmed HTLV-1/2-reactivity on the HTLV-I/II Vironostika ELISA kit, but six out of 35 sera were non-reactive on the Biokit ELISA test (Table 1). Figure 1 presents the results obtained on WB 2.4 analyses, showing HTLV-1 seropositivity in the majority of samples ( 25 out of 35 sera) and the absence of HTLV-2-positive serum. In addition, WB disclosed one HTLV-positive sample (lane 34), and nine indeterminate sera. Among them, HTLV-1 Gag indeterminate profile (HGIP), defined as the presence of p19, p26, p28, p32 and p36 without p24 or env gp21 and gp46, was detected in three serum samples (lanes 12,19 , and 32). One serum presented a pattern suggestive of HTLV-1 but with no GD21 (lane 11). Curiously, all samples that were negative on the Biokit ELISA test were indeterminate by WB (Table 1 and Fig. 1).

The major demographic characteristics of HTLV-1/2-positive individuals are disclosed in Table 2; all blood donors originated from southern Peru, mostly from Arequipa. The majority of them were male, and no difference in age or gender was observed (Table 2). In addition, no relationship with factors associated with retroviral infection was detected (data not shown), except for three individuals who reported previous blood transfusion (two persons) and tattooing (one person). Regarding other blood-transmitted diseases, HTLV co-positives with hepatitis B and syphilis were detected: antibody to hepatitis B core antigen (anti-HBc) was detected in four sera, hepatitis B surface antigen ( $\mathrm{HBsAg}$ ) in one serum, and rapid plasma reagin (RPR anti-T. pallidum) in another serum. No sera were HIV/HTLV co-infected.

\section{DISCUSSION}

Seroepidemiological studies in native South American showed HTLV-1 and HTLV-2 carrier state: HTLV-1 foci in groups of Andean highlands of Colombia, Peru, Bolivia, Argentina and Chile, and HTLV-2 in natives of the lowlands of Brazil, Paraguay and Chile ${ }^{7,13,22}$.

Although Peru harbors four different ethnic groups: the Quechuas of Inca origin, Nikkei of Japanese descent, Mestizo of mixed white-Indian, and blacks or mulattos of African origin, HTLV-1 has been detected in all groups, and a molecular clock study confirmed a post-Columbian introduction of virus in the country ${ }^{27}$.

The absence of HTLV-2 positive sera and HIV/HTLV co-infection in the present study could be explained by the rules of Peruvian blood banks, which exclude patients with STDs, MSM, and individuals who have been in prison during the last six months. Indeed, these results could be a consequence of community isolation and the uncommon injection drug use (IDU) in the country ${ }^{11}$, where the latter is thought to be the major route of HTLV-2 transmission in urban populations. In contrast to Brazil, where HTLV-2 is endemic among Amerindians and IDU 2,4,5,13,21,22,23,25, HTLV-2 has only been detected in Peru in two Amazonian Indians and in MSM from cities near the Amazon ${ }^{19,28}$. Interestingly, only 11 (0.4\%) out of 2,732 sera were HIV positive, none of which were co-infected with HTLV.

Regarding the sensitivity and specificity of the HTLV screening kits employed in the present study, six out of nine indeterminate sera by WB were HTLV antibody negative on the ELISA screening kit that contains only HTLV-1 and HTLV-2 recombinant antigens (Biokit), suggesting that this kit is more specific for HTLV-1/2 antibody detection than the Vironostika kit. We could not, however, exclude HTLV seroconversion, and we recommend following-up of such individuals. Although the HGIP WB profile has been described in sera from individuals of tropical countries where malaria is endemic and does not denote true HTLV infection ${ }^{18}$, we recently described this WB profile in an individual during HTLV-seroconversion ${ }^{15}$. In addition, we described an inability to detect all HTLV-seroreactive samples (mostly HTLV-2 infected) when only one ELISA is employed for screening in high-risk populations from São Paulo, 
QUISPE, N.C.S.; FERIA, E.B.; SANTOS-FORTUNA, E. \& CATERINO-DE-ARAUJO, A. - Confirming the presence of HTLV-1 infection and the absence of HTLV-2 in blood donors from Arequipa, Peru. Rev. Inst. Med. trop. S. Paulo, 51(1): 25-29, 2009.

Table 1

Results obtained by screening and confirmatory tests for HTLV-1 and HTLV-2 infections in blood donors from Arequipa, Peru

\begin{tabular}{|c|c|c|c|c|}
\hline Sample code & ELISA* Vironostika ${ }^{\circledR}$ & ELISA** Vironostika® & ELISA** Biokit & WB pattern** WB 2.4 \\
\hline 4 & + & + & - & Indet. p24 \\
\hline 5 & + & + & + & HTLV-1 \\
\hline 6 & + & + & + & HTLV-1 \\
\hline 7 & + & + & + & HTLV-1 \\
\hline 8 & + & + & + & HTLV-1 \\
\hline 9 & + & + & + & HTLV-1 \\
\hline 10 & + & + & + & HTLV-1 \\
\hline 11 & + & + & + & Indet.p19, p24, p26, p28, p36, gp46-I \\
\hline 12 & + & + & + & Indet. (HGIP) \\
\hline 13 & + & + & + & HTLV-1 \\
\hline 14 & + & + & + & HTLV-1 \\
\hline 15 & + & + & + & HTLV-1 \\
\hline 16 & + & + & + & HTLV-1 \\
\hline 17 & + & + & + & HTLV-1 \\
\hline 18 & + & + & + & HTLV-1 \\
\hline 19 & + & + & - & Indet. (HGIP) \\
\hline 20 & + & + & + & HTLV-1 \\
\hline 21 & + & + & + & Indet. p19 \\
\hline 22 & + & + & + & HTLV-1 \\
\hline 23 & + & + & + & HTLV-1 \\
\hline 24 & + & + & + & HTLV-1 \\
\hline 25 & + & + & + & HTLV-1 \\
\hline 26 & + & + & + & HTLV-1 \\
\hline 27 & + & + & - & Indet. p24, p28 \\
\hline 28 & + & + & - & Indet. p19 \\
\hline 29 & + & + & + & HTLV-1 \\
\hline 30 & + & + & + & HTLV-1 \\
\hline 31 & + & + & + & HTLV-1 \\
\hline 32 & + & + & - & Indet. (HGIP) \\
\hline 33 & + & + & + & HTLV-1 \\
\hline 34 & + & + & + & HTLV \\
\hline 35 & + & + & + & HTLV-1 \\
\hline 36 & + & + & + & HTLV-1 \\
\hline 37 & + & + & - & Indet. p24, p28 \\
\hline 38 & + & + & + & HTLV-1 \\
\hline
\end{tabular}

*Assay conducted in Arequipa; ** Assays conducted in Brazil. + denote reactive sera, - denote non-reactive sera, according to Materials and Methods. Indet: HTLVIndeterminate, HGIP: HTLV-1 gag indeterminate pattern (p19, p26, p28, p32, p36). Enzyme-linked immunosorbent assays: Vironostika ${ }^{\circledR}$ HTLV-I/II, BioMerieux, France, and BioELISA HTLV-I+II (r) (BioKit S.A., Spain). Western Blot assay: WB 2.4, Genelabs, Singapore.

Brazil $^{5,6,14,15}$, and suggested the use of two ELISAs of different compounds and formats for screening in this country (contrary to the recommendation of the Ministry of Health of Brazil ${ }^{16}$. The same strategy has been conducted in Argentina, where the combination of two HTLV screening assays was shown to be useful for blood banks ${ }^{3}$. The significance of the indeterminate profile (by WB) in sera from blood donors of Arequipa is unknown, but malaria should be excluded since this is not an endemic area. Unfortunately, this work was limited by its cross-sectional design, and follow-up of such individuals was not done. More studies are in progress in order to confirm the Biokit ELISA as the most appropriate for screening in regions were HTLV-1 and HTLV-2 are endemic.

Aside from clinical diagnosis, HTLV-1/2 confirmatory tests were not mandatory in Peruvian blood banks making it impossible to know the actual prevalence of such viruses among blood donors and to compare the results. 


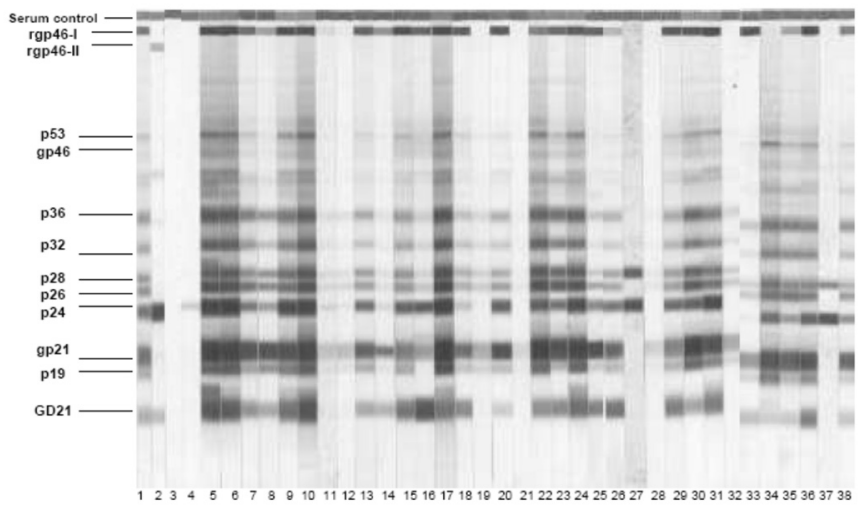

Fig. 1 - Patterns of HTLV-reactivity obtained from serum samples of blood donors from Arequipa, Peru using WB 2.4 (Genelabs, Singapore). Lanes 1, 2 and 3 denote HTLV-1, HTLV-2 and HTLV-negative controls; Lanes 4 to 28 correspond to serum samples from blood donors.

Table 2

Demographic characteristics of HTLV-1/2-seropositive individuals $(\mathrm{n}=35)$

\begin{tabular}{lll}
\hline Age (years) & Range & $19-54$ \\
& Mean & 34.6 \\
& Female & 35.0 \\
& Male & 34.6 \\
\hline Gender (n) & Female & 8 \\
& Male & 27 \\
\hline Origin (n) & Arequipa & 27 \\
& Puno & 5 \\
& Cuzco & 3 \\
\hline
\end{tabular}

$\mathrm{N}=$ number of individuals.

The huge number of HTLV-1-infected men among blood donors could be a consequence of the high number of donors of this gender. An age-and-gender-cohort effect due to the characteristics of blood donors worldwide could not be excluded.

Finally, the main result that emerges from this study is the high prevalence of HTLV-1 among individuals without behavioral risk factors for acquiring retroviruses, which confirms Arequipa as an endemic region of HTLV-1. The correct diagnosis of HTLV-1 is important for prompt attention and counseling these individuals to avoid vertical and sexual virus transmission. Indeed, the results obtained suggest that HTLV-2 has probably not yet been introduced in healthy persons from southern Peru.

\section{RESUMO}

\section{Confirmação da presença de infecção por HTLV-1 e ausência de} infecção por HTLV-2 em doadores de sangue de Arequipa, Peru

Estudos epidemiológicos conduzidos no Peru apontam a infecção por HTLV-1 como prevalente em diferentes grupos étnicos e por
HTLV-2 restrita a alguns índios da região Amazônica e a homens que fazem sexo com homens. Não existem dados sobre a infecção por HTLV-1/2 em doadores de sangue de Arequipa, região montanhosa do sul do Peru. Portanto, o presente estudo pesquisou anticorpos anti-HTLV-1 e HTLV-2 em 2.732 doadores de sangue desta região geográfica. Foram utilizados na triagem sorológica os testes imunoenzimáticos (ELISA) e para confirmação dos resultados o Western Blot (WB). Soros reagentes no ELISA tiveram suas bolsas de sangue descartadas. Os resultados obtidos foram analisados de acordo com características demográficas dos indivíduos. Trinta e cinco soros $(1,2 \%)$ resultaram HTLV-1/2 reagentes no ELISA, 25 confirmaram infecção por HTLV-1 no WB. Um soro resultou HTLV positivo e os nove soros restantes resultaram em padrão indeterminado no WB: três com perfil HTLV-1 Gag indeterminado. A média de idade dos indivíduos HTLV positivos foi de 34,6 anos; 27 do gênero masculino e oito do gênero feminino. Todos eram da região sul do país: 27 de Arequipa, cinco de Puno e três de Cuzco. Foi detectada co-positividade HTLV com hepatite B (cinco soros) e sífilis (um soro). Nenhum soro resultou positivo para a co-infecção HIV/HTLV. Havia dois indivíduos com transfusão prévia e um com tatuagem. Este trabalho confirma pela primeira vez infecção por HTLV-1 e ausência de infecção por HTLV-2 em doadores de sangue de Arequipa, sul do Peru e sugere que a transmissão vertical seja a principal via de transmissão/aquisição de HTLV-1 nesta região geográfica.

\section{REFERENCES}

1. ALARCÓN, J.O.; FRIEDMAN, H.B.; MONTANO, S.M. et al. - High endemicity of human T-cell lymphotropic virus type I among pregnant women in Peru. J. acquir. immune Defic. Syndr., 42: 604-609, 2006.

2. ALCÂNTARA, L.C.J.; SHINDO, N.; VAN DOOREN, S. et al. - Brazilian HTLV type 2a strains from intravenous drug users (IDUs) appear to have originated from two sources: Brazilian Amerindians and European/North American IDUs. AIDS Res. hum. Retrovir., 19: 519-523, 2003.

3. BERINI, C.A.; PASCUCCIO, S.; BAUTISTA, C.T. et al. - Comparison of four commercial screening assays for the diagnosis of human T-cell lymphotropic virus types 1 and 2. J. virol. meth., 147: 322-327, 2008.

4. CASSEB, J.; CATERINO-DE-ARAUJO, A.; HONG, M.A. et al. - Prevalence of HTLV-I and HTLV-II infections among HIV-1-infected asymptomatic individuals in São Paulo, Brazil. Rev. Inst. Med. trop. S. Paulo, 39: 213-215, 1997.

5. CATERINO-DE-ARAUJO, A.; SANTOS-FORTUNA, E.; MELEIRO, M.C. et al. Sensitivity of two ELISA tests in relation to Western blot in detecting HTLV-I and HTLV-II infections among HIV-1-infected patients from São Paulo, Brazil. Diagn. Microbiol. infect. Dis., 30: 173-182, 1998.

6. CATERINO-DE-ARAUJO, A.; CASSEB, J.S.R.; NEITZERT, E. et al. - HTLV-I and HTLV-II infections among HIV-1 seropositive patients in São Paulo, Brazil. Europ. J. Epidem., 10: 165-171, 1994.

7. FUJIOSHI, T.; LI, H.C.; LOU, H. et al. - Characteristic distribution of HTLV type I and HTLV type II carriers among native ethnic groups in South America. AIDS Res. hum. Retrovir., 15: 1235-1239, 1999.

8. GOTUZZO, E.; CABRERA, J.; DEZA, L. et al. - Clinical characteristics of patients in Peru with human $\mathrm{T}$ cell lymphotropic virus type-1-associated tropical spastic paraparesis. Clin. infect. Dis., 39: 939-944, 2004.

9. GOTUZZO, E.; DE LAS CASAS, C.; DEZA, L. et al. - Tropical spastic paraparesis and HTLV-I infection: clinical and epidemiological study in Lima, Peru. J. neurol. Sci., 143: 114-117, 1996. 
QUISPE, N.C.S.; FERIA, E.B.; SANTOS-FORTUNA, E. \& CATERINO-DE-ARAUJO, A. - Confirming the presence of HTLV-1 infection and the absence of HTLV-2 in blood donors from Arequipa, Peru. Rev. Inst. Med. trop. S. Paulo, 51(1): 25-29, 2009.

10. GOTUZZO, E.; MOODY, J.; VERDONCK, K. et al. - Frequent HTLV-1 infection in the offspring of Peruvian women with HTLV-1-associated myelopathy/tropical spastic paraparesis or strongyloidiasis. Rev. panamer. Salud publ., 22: 223-230, 2007.

11. GOTUZZO, E.; SANCHEZ, J.; ESCAMILLA, J. et al. - Human T cell lymphotropic virus type I infection among female sex workers in Peru. J. infect. Dis., 169: 754-759, 1994.

12. GOTUZZO, E. - Risk of transfusion-transmitted human T-cell lymphotropic virus-type I in Latin America. Int. J. infect. Dis., 4: 59-61, 2000.

13. ISHAK, R.; VALLINOTO, A.C.R.; AZEVEDO, V.N. \& ISHAK, M.O.G. -Epidemiological aspects of retrovirus (HTLV) infection among Indian populations in the Amazon region of Brazil. Cadern. Saúde publ. (Rio de J.), 19: 101-114, 2003.

14. JACOB, F.; SANTOS-FORTUNA, E.; AZEVEDO, R.S. \& CATERINO-DE-ARAUJO, A. - Performances of HTLV serological tests in diagnosing HTLV infection in highrisk population of São Paulo, Brazil. Rev. Inst. Med. trop. S. Paulo, 49: 361-364, 2007.

15. JACOB, F.; SANTOS-FORTUNA, E.; AZEVEDO, R.S. \& CATERINO-DE-ARAUJO, A. - Serological patterns and temporal trend of HTLV-1/2 infection in high-risk populations attending Public Health Units of São Paulo, Brazil. J. clin. Virol., 42: 149-155, 2008.

16. JACOB, F.; SANTOS-FORTUNA, E. \& CATERINO-DE-ARAUJO, A. - Algoritmo de testes sorológicos de triagem para infecção por HTLV-1/2 usado no Instituto Adolfo Lutz de São Paulo. Bol. epidem. paul., 5(49), janeiro, 2008.

17. LAGUNA-TORRES, V.A.; PÉREZ-BAO, J.; CHAUCA, G. et al. - Epidemiology of transfusion-transmitted infections among multi-transfused patients in seven hospitals in Peru. J. clin. Virol., 34 (suppl. 2): S61-68, 2005.

18. MAHIEUX, R.; HORAL, P.; MAUCLÈRE, P. et al. - Human T-cell lymphotropic virus type 1 gag indeterminate Western blot patterns in Central Africa: relationship to Plasmodium falciparum infection. J. clin. Microbiol., 38: 4049-4057, 2000

19. MEDEOT, S.; NATES, S.; RECALDE, A. et al. - Prevalence of antibody to human T cell lymphotropic virus types $1 / 2$ among aboriginal groups inhabiting northern Argentina and the Amazon region of Peru. Amer. J. trop. Med. Hyg., 60: 623-629, 1999.

20. MINISTERIO DEL SALUD DEL PERU - Da. Normas y procedimientos PRONAHRBAS Programa Nacional de Hemoterapia y Bancos de Sangre / Peru. Lima, Ministerio del Salud, 1998. (Decreto Supremo numero 002-92-AS).
21. MORIMOTO, H.K.; CATERINO-DE-ARAUJO, A.; MORIMOTO, A.A. et al. Seroprevalence and risk factors for human T-cell lymphotropic virus type 1 and 2 infection in human immunodeficiency virus (HIV)-infected patients attending AIDS referral center health units in Londrina and other communities in Paraná, Brazil. AIDS Res. hum. Retrovir., 21: 256-262, 2005

22. ROUCOUX, D.F. \& MURPHY, E.L. - The epidemiology and disease outcomes of human T-lymphotropic virus type II. AIDS Rev., 6: 144-154, 2004.

23. SALEMI, M.; LEWIS, M.; EGAN, J.F. et al. - Different population dynamics of human T cell lymphotropic virus type II in intravenous drug users compared with endemically infected tribes. Proc. nat. Acad. Sci. (Wash.), 96: 13253-13258, 1999.

24. SANCHEZ-PALACIOS, C.; GOTUZZO, E.; VANDAMME, A.M. \& MALDONADO, Y. - Seroprevalence and risk factors for human T-cell lymphotropic virus (HTLV-I) infection among ethnically and geographically diverse Peruvian women. Int. J. infect. Dis., 7: 132-137, 2003

25. SHINDO, N.; ALCÂNTARA, L.C.J.; VAN DOOREN, S. et al. - Human retroviruses (HIV and HTLV) in Brazilian Indians: serological study and molecular epidemiology of HTLV type 2 isolates. AIDS Res. hum. Retrovir., 18: 71-77, 2002.

26. TRUJILlO, L.; MUÑOZ, D.; GOTUZZO, E.; YI, A. \& WATTS, D.M. - Sexual practices and prevalence of HIV, HTLV-I/II, and Treponema pallidum among clandestine female sex workers in Lima, Peru. Sex. transm. Dis., 26: 115-118, 1999.

27. VAN DOOREN, S.; GOTUZZO, E.; SALEMI. M. et al. - Evidence for a post-Columbian introduction of human T-cell lymphotropic virus in Latin America. J. gen. Virol., 79: 2695-2708, 1998

28. ZUNT, J.R.; LA ROSA, A.M.; PEINADO, J. et al. - Risk factors for HTLV-II infection in Peruvian men who have sex with men. Amer. J. trop. Med. Hyg., 74: 922-925, 2006

29. ZURITA, S.; COSTA, C.; WATTS, D. et al. - Prevalence of human retroviral infection in Quillabamba and Cuzco, Peru: a new endemic area for human T cell lymphotropic virus type 1. Amer. J. trop. Med. Hyg., 56: 561-565, 1997.

Received: 12 February 2008

Accepted: 27 November 2008 